\title{
Discovery Learning to Develop Student Reflective Thinking Ability and Self-Efficacy
}

\author{
Mega Kusuma Listyotami ${ }^{1}$, Sri Hastuti Noer ${ }^{2}$, Een Yayah Haenilah ${ }^{3}$ \\ 1,2,3 Universitas Lampung \\ ${ }^{1}$ Correspondence Address; megakusumalistyotami@gmail.com
}

\begin{abstract}
The research and development aims to produce a discovery learning model that is oriented towards the student ability of reflective thinking and self-efficacy. The research was conducted using the Research \& Development (R \& D) method. The research and development model used refers to the procedure of R \& D development by Gall and Borg by Sukmadinata that is ADDIE. The steps for implementing the research and development strategy include; (1) analysis, (2) design, (3) development, (4) implementation, (5) evaluation. The Data collecting methods and instruments are used tests and non-tests. The Data collection techniques using observation, interviews, questionnaires, and tests. The Data analysis techniques used in research and development are quantitative and qualitative descriptive. The results showed that the discovery learning model that was oriented towards the student ability of reflective thinking and selfefficacy was effective to improve the student ability of reflective thinking and self-efficacy respectively by $77 \%$ and $30 \%$.
\end{abstract}

Keywords: Discovery Learning, Relative thinking, dan Self-Efficacy

\section{INTRODUCTION}

The Education is never separated from the learning process in learning activities. The Learning activities can take place as reflected by student activities (Yusuf, 2015). The student activity in the mathematics learning, which involves the process of thinking in every human being to achieve kinds of competencies, skills, and attitudes (Sani, 2016; Mentari, 2018). the Mathematics has an important role in various disciplines and develops the mindset of every human being (Somawati, 2018). The importance of mathematics in learning starts from elementary school to college. The Mathematics is important as means of developing the reasoning ability of thinking ability (Rasyid, 2017). The thinking skills that must be developed are the abilityof thinking reflective and self-efficacy to achieve the success of the learning process (Setiani, 2017; Mentari, 2018). The Learning is good and successful if the factors influence of the learning system are mutually (Haryati, 2017). The success achievement of a learning is supported by optimal activity achievement with an atmosphere behaviour that supports the interesting learning process. The success of the learning process is also caused the teachers ability in developing learning models that are oriented towards increasing the intensity of the student effective involvement in the learning process. The weak of learning process is a lack of the teacher's supporting in pursuing the best learning process in developing students' thinking skills (Angkotasan, 2013). This means needs for applying good and appropriate learning models that involve the students actively (Baskara Putra, 2017). The Self efficacy influences the learning process, the teachers that have high self-efficacy be able to improve the quality of learning by showing good commitment to encourage the student achievement (Setiani, 2017). So it is important to choose the apropriate strategy by applying a learning model that is able to develop reflective thinking skills and self-efficacy, one of model learning is the discovery learning model. 
Discovery learning is an based learning model that developed on constructivism theory, it emphasizes in the development of cognitive, affective, and psychomotor aspects in a balanced manner by requiring students to develop active learning by finding themselves and investigating themselves so that they can find their own concepts and theories of learning (Istikomah, 2013; Wardani UA, 2014; Yusuf M. d., 2015; Haryanti, 2016; Jalil, 2016; Rahayu, 2016; Fadriati, 2017; Late, 2017; Rosdiana, 2017; Sukmasari, 2017). The development of discovery learning models as an effort to assist teachers in overcoming student learning difficulties related to reflective thinking skills and self-efficacy. Discovery learning encourages the students to become active agents in their own learning processes. The teacher does not present to students directly in the learning, but the student must discover through experiments. The teacher only guides students to find two approaches about discovery learning, the first approach emphasizes the discovery of the learning process, the second approach focuses on developing knowledge. The reflective thinking process that means high-level thinking skills that are based on reason and purpose by involving problem solving, formulating conclusions and relating matters, and making decisions when someone uses meaningful and effective skills for a particular context and types of thinking assigmen (Ellianawati et al., 2014; Al Majid, 2015; Sani, 2016; Haryati, 2017; Rasyid, 2017; Mentari, 2018). It means that with the discovery knowledge actively in the students when the students reorganize their experiences based on students' cognitive knowledge and structure. The expectations and goals that need to be achieved by students for the ability to think reflectively in learning mathematics (Rasyid, 2017). The ability of mathematical reflective thinking needs to be supported by a didactic design by the teacher in the classroom (Nindiasari, 2016). Among the several indicators of ability that must be achieved so that optimal achievement in learning according to Noer (2010: 43-44) includes:

a. Reacting is reacting with personal understanding of events, stimulation, or mathematical problems by focusing on the nature of the situation

b. Comparing is analyzing and clarifying what individual experiences are believed by comparing reactions with other experiences, such as referring to a general principle or a theory.

c. Contemplating is prioritizing deep personal understanding. In this case focus on a personal level in processes such as outlining, informing, considering and reconstructing a situation or problem.

Moreover, the ability of self-efficacy, the person must have confidence in the reflective thinking process. Reflection is broadly defined as active, persistent and belief. Belief in this case plays an important role because in reflection contains how the person can evaluate themselves. A person's evaluation of his ability or competence to perform a task, achieve goals, and overcome obstacles are definitions of self-efficacy. Self-efficacy is an important thing to have tbecause it make students are motivated to learn through the use of self-regulation as a process of goal setting, self-evaluation, and setting strategies are used related to individual's assessment related own abilities as a result of cognitive processes in the form of decisions. beliefs, expectations about the extent of individuals estimate their abilities in doing tasks or 
actions needed to achieve the results (Setiani, 2017; Isfayani, 2018; Putra et al., 2018; Masri, 2018). Students 'self-efficacy and mathematical abilities also have a direct effect on students' mathematical performance. According to Noer (2012: 805), the aspects are used to measure self-efficacy include:

a. The authentic mastery experiences, namely capability indicators based on performance on prior experience.

b. The vicarious experiences, namely evidence based on competence and informative comparison with the results achieved by others.

c. The verbal persuasion (verbal persuasions), which refers to direct feedback / words from the teacher or a more mature person.

d. Psychological index, which is an assessment of abilities, strengths and weaknesses.

Regarding the benchmarks of ability to think reflective and self-efficacy, the development of research by applying the discovery learning model in learning. As for previous research and development that has used discovery learning models including: research and development affect the ability; understanding of science, science process skills, concept understanding, effectiveness and learning outcomes, improvement of concept understanding, and problem solving skills (Istikomah, 2013; Yusuf M. d., 2015; Haryanti, 2016; Rosdiana, 2017; Late, 2017; Sukmasari, 2017).

Based on the previous research, this research and development also applies the similiar model, that is discovery learning model with renewal to find out how to produce discovery learning models that are oriented towards the student ability to thinking reflective and selfefficacy .

\section{THE RESEARCH METHODS}

i solve the mathemathical problems. The test is used a test of students' reflective thinking ability with indicators; reacting, comparing, and contemplating. The questionnaire was used a self-efficacy questionnaire with 4 measurement aspect scales, these were performance achievement based on experience, other people's experiences, verbal persuasion, and psychology index. The data analysis techniques is used in research and development are quantitative and qualitative descriptive. The hypothesis of this research is the design of discovery learning models to develop the ability of reflective thinking and self-efficacy students meet the criteria of valid, practical, and effective in improving the ability of reflective thinking and student self-efficacy. The design of research and development design can be seen in Figure 1 . 


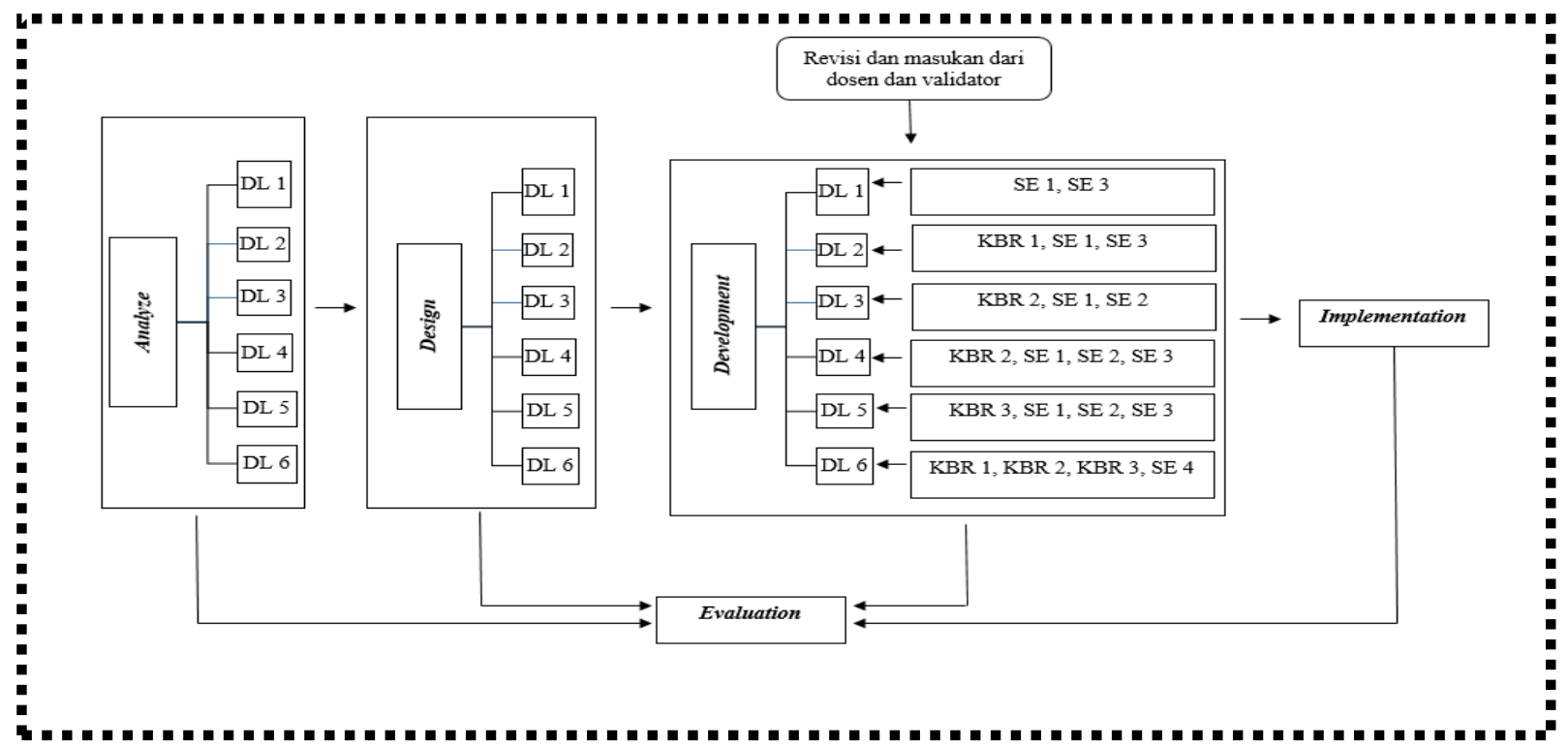

Figure 1. The research design and the development of Discovery Learning Model

\section{The figure description :}

DL $1: 1^{\text {st }}$ Discovery Learning Phase

DL $2: 2^{\text {nd }}$ Discovery Learning Phase

DL $3: 3^{\text {rd }}$ Discovery Learning Phase

DL $4: 4^{\text {th }}$ Discovery Learning Phase

DL $5: 5^{\text {th }}$ Discovery Learning Phase

DL $6: 6^{\text {th }}$ Discovery Learning Phase

SE $1: 1^{\text {st }}$ Self-Efficacy Aspect

SE $2: 2^{\text {nd }}$ Self-Efficacy Aspect

SE $3: 3^{\text {rd }}$ Self-Efficacy Aspect

SE $4: 4^{\text {th }}$ Self-Efficacy Aspect

KBR 1 : Indicator of the 1st Reflective Thinking Ability KBR 2: Indicator of the 2nd Reflective Thinking Ability KBR 3 : Indicator of the 3rd Reflective Thinking Ability

\section{THE RESULTS OF THE RESEARCH AND THE DISCUSSION}

The discovery learning design development model in this studyresearch use the ADDIE learning design development model which stands for analysis, design, development, implementation, and evaluation. The stages in research and development include:

\section{Analysis stage}

In the learning mathematics identified several problems experienced by students, namely: (1) the student still difficulties in identifying contextual problems (daily life) into the form of mathematical models; (2) the student still difficulties in determining the strategies are used in answering math problems; (3)the student still difficulties in giving reasons for answers on the mathematical problem; (4) The student still difficulties to do the questions that require high- 
level thinking skills. Some of the problems are faced by the students that are related to reflective thinking skills and student self-efficacy. The Problems experienced by students in learning mathematics have an impact on not optimal learning outcomes are obtained by students. Whereas in the school learning already use discovery learning models actively in accordance with the 2013 curriculum scientific approach, but its learning has not been effective enough to foster and maximize the ability of the reflective thinking and student self-efficacy.

\section{Design Stage}

After doing the analysis are known some problems, it is necessary to design appropriate to develop the ability of reflective thinking and self-efficacy of students through discovery learning models. It is necessary to add indicators of the ability of reflective thinking and aspects of self-efficacy of students in the stages of discovery learning models, which include: (1) in the first stage of stimulation was added to the self-efficacy aspect, (2) the second stage was performance achievement and self-efficacy aspects, (3) the third stage was verbal persuasion. But in the second stage problem identification was added with an indicator of the ability to reflect reflective; (1) first, namely reacting, self-efficacy aspects, (2) second, the performance achievement and self-efficacy aspect,(3) verbal persuasion. After that in the third stage of data collection (data collection) added reflective thinking ability indicators include; (1) the first, comparing, self-efficacy aspects, (2) The second, achievement of performance and aspects of self-efficacy, (3) The third, the experience of others. In the fourth stage of data processing (data processing) added reflective thinking ability indicators include; (1)the first, comparing, selfefficacy aspects, (2) the second, achievement of performance, aspects of self-efficacy, (3) the third, the experience of others, and aspects of self-efficacy, (4) the fourth, verbal persuasion. In the fifth stage of verification (verification) added a reflective thinking ability indicator includes; (1) the first, contemplating, self-efficacy aspects, (2) the second, achievement of performance, aspects of self-efficacy, (3) the third, the experience of others, and aspects of self-efficacy, (4)the fourth, verbal persuasion. In the sixth stage generalization for the test phase is added to the reflective thinking ability indicator including; (1) the first is reacting, (2) indicator of the second ability of reflective thinking is comparing, (3) indicators of the ability of the third reflective thinking is contemplating, (4) for the self-reflection stage, the selfefficacy aspect is a psychological index.

\section{Development stages}

After doing the design, it can be done development based on the discovery learning model step. There are 6 phases of discovery learning model that must be passed, while for self-efficacy aspects there are 4 phases with 3 reflective thinking ability indicators.

\section{Implementation Stages}

The implementation phase of discovery learning models to develop students' reflective thinking skills and self-efficacy are: (1) stimulation, the teacher gives the questions about the subject matter that has been studied by students relating to the material ; (2) problem statement, identifying problems by reacting using personal understanding. At the problem identification stage, the students identify problems by linking knowledge previously learned by students that relates to the material being studied by students; (3) the data collection, data collection begins 
by utilizing the knowledge that has been owned by students previsously and then searching literature and observing objects; (4) the data processing, data processing by analyzing and clarifying data that has been obtained at the data collection stage. Data processing using knowledge possessed by previous students. The data processing also uses individual experience in groups, the teacher helps students by giving feedback; (5) verification, proof by informing answers and reconstructing situations or problems; (6) generalization, the generalization stage is carried out by drawing conclusions with the knowledge that has been obtained by students, then a test is conducted to test students' reflective thinking skills and self-reflection to know the students' understanding in strengths and weaknesses and if there is a failure to find out where students fail

\section{Evaluation Stages}

The evaluation is carried out to determine whether the development achieved is in appropriate with the objectives. the evaluation at ADDIE stage is carried out by the researcher with guidance from the supervisor, then produces a product in the form of discovery learning oriented towards the ability to think reflective and self-efficacy of students.

The research was conducted to determine the effectiveness of the results towards the development of discovery learning models on the ability of reflective thinking and student selfefficacy. The results of the ability of students' initial reflective thinking were obtained from the results of the pretest scores conducted at the beginning of the meeting before learning was carried out. The recapitulation of the results of the pretest scores on students' initial reflective thinking skills is presented in Table 1.

Tabel 1. The Data on the Ability of Students' Initial Reflective Thinking

\begin{tabular}{cccccc}
$\begin{array}{c}\text { The Research } \\
\text { Group }\end{array}$ & $\begin{array}{c}\text { Amount of } \\
\text { the student }\end{array}$ & $\begin{array}{c}\text { The } \\
\text { Average }\end{array}$ & $\begin{array}{c}\text { Standard } \\
\text { Deviation }\end{array}$ & $\begin{array}{c}\text { The Lowest } \\
\text { Value }\end{array}$ & $\begin{array}{c}\text { The Highest } \\
\text { Value }\end{array}$ \\
\hline PDL & 35 & 28,155 & 12,965 & 8,330 & 54,170 \\
\hline DL & 35 & 29,644 & 10,405 & 8,330 & 50,000 \\
\hline \multicolumn{6}{c}{ Ideal Maximum Score $=100$} \\
\hline
\end{tabular}

\footnotetext{
Description:

PDL = Discovery Learning Development

$\mathrm{DL}=$ Discovery Learning

Min $=$ Minimum Value

Max = Maksimum Value

$\overline{\mathrm{x}} \quad=$ Average

$\mathrm{s} \quad=$ Standard Divination
}

In the table 1 , it can be seen that the average score of the initial reflective thinking ability of PDL class students is lower than the DL class students. The standard deviation in the DL class is lower than the PDL class. This shows that the distribution of scores on the ability to think reflective early in PDL class students is more heterogeneous than DL class students. The minimum score obtained by students in the PDL class is the same as the minimum score obtained by students in the DL class. While the maximum score obtained by students in the PDL class is lower than the DL class students. The final reflective thinking ability data was 
obtained from the posttest results that is conducted after the learning was done. The recapitulation of the results of the posttest score on the final mathematical reflective thinking ability is presented in Table 2 .

Tabel 2. The data on Students' Final Reflective Thinking Ability

\begin{tabular}{cccccc}
$\begin{array}{c}\text { Group } \\
\text { Research }\end{array}$ & $\begin{array}{c}\text { Amount of } \\
\text { Student }\end{array}$ & Average & $\begin{array}{c}\text { Standard } \\
\text { Divination }\end{array}$ & $\begin{array}{c}\text { The lowest } \\
\text { Value }\end{array}$ & $\begin{array}{c}\text { The Highest } \\
\text { Value }\end{array}$ \\
\hline PDL & 35 & 83,571 & 5,931 & 72,917 & 97,917 \\
\hline DL & 35 & 75,477 & 7,796 & 54,167 & 87,500 \\
\hline \multicolumn{7}{c}{ Ideal Maximum Score $=100$} \\
\hline
\end{tabular}

\section{Description:}

PDL = Discovery Learning Development

$\mathrm{DL} \quad=$ Discovery Learning

Min = Minimum Value

Max = Maximum Value

$\overline{\mathrm{x}} \quad=$ Average

$\mathrm{s} \quad=$ Standard Divination

In Table 2, it can be seen that the average score of students' ability on thinking reflective in the PDL class is higher than the DL class. The highest score in the PDL class was higher than the highest score in the DL class and the lowest score in the PDL class was higher than the lowest score of the DL class. The standard deviation of the PDL class is lower than the standard deviation of the DL class. This shows that the distribution of scores of students' ability in thinking reflective in the DL class is more heterogeneous than the PDL class. After the pretest and posttest were obtained the initial score and final score data were then processed to get the data gain of reflective thinking ability and student self-efficacy. Data recapitulation of the ability of students to reflect reflective thinking following the PDL model and DL learning is presented in Table 3.

Tabel 3. The Gain data of Students' Reflective Thinking Ability

\begin{tabular}{|c|c|c|c|c|c|c|c|}
\hline No & Class & Value & $\mathrm{N}$ & $X \min$ & Xmaks & $\overline{\mathbf{x}}$ & $\mathrm{N}$-gain Average \\
\hline \multirow[t]{2}{*}{1} & \multirow[t]{2}{*}{ PDL } & Pretest & \multirow[t]{2}{*}{35} & 8,33 & 54,17 & 28,15 & \multirow[t]{2}{*}{0,77} \\
\hline & & Posttest & & 72,91 & 97,91 & 83,57 & \\
\hline \multirow[t]{3}{*}{2} & \multirow[t]{2}{*}{$\mathrm{DL}$} & Pretest & \multirow[t]{2}{*}{35} & 8,33 & 50,00 & 29,64 & \multirow[t]{2}{*}{0,65} \\
\hline & & Posttest & & 54,16 & 87,50 & 75,47 & \\
\hline & \multicolumn{7}{|c|}{ Ideal Maximum Score $=100$} \\
\hline
\end{tabular}

Description:

PDL = Discovery Learning Development

$\mathrm{DL}=$ Discovery Learning

Min = Minimum Value

Max = Maximum Value

$\overline{\mathrm{x}} \quad=$ Average

$\mathrm{s} \quad=$ Standard Divination 
In Table 3, it can be seen that the average gain index of reflective thinking students that use the development of discovery learning is higher than the average gain index of reflective thinking students that use the discovery learning. Based on Table 3 the average gain index of the experimental class is 0.77 , this means that the improvement of students' reflective thinking skills using the development of discovery learning is included in the improvement with high criteria. While the improvement of students' reflective thinking ability using discovery learning is included in the improvement with the medium criteria with the average gain index of the control class that is equal to 0.65 . The Primary data of the students' self-efficacy were obtained from the scale scores conducted at the beginning of the meeting before learning was conducted. The recapitulation of The Primary Dataof the scale scores result of students' self-efficacy is presented in Table 4.

Tabel 4.The Primary Data of Self-efficacy Student

\begin{tabular}{cccccc} 
Group Research & $\begin{array}{c}\text { Amount of } \\
\text { Student }\end{array}$ & Average & $\begin{array}{c}\text { Standard } \\
\text { Divination }\end{array}$ & $\begin{array}{c}\text { The Lowest } \\
\text { Value }\end{array}$ & $\begin{array}{c}\text { The Highest } \\
\text { Value }\end{array}$ \\
\hline PDL & 35 & 80,486 & 7,278 & 68 & 96 \\
\hline DL & 35 & 81,629 & 6,778 & 66 & 97 \\
\hline \multicolumn{7}{c}{ Ideal Maximum Score $=100$} \\
\end{tabular}

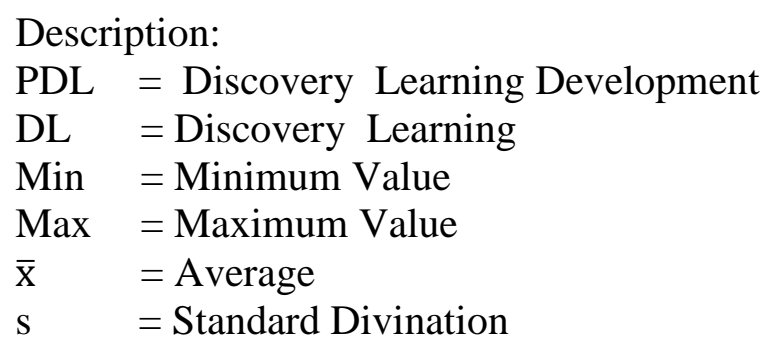

Based on Table 4 it can be seen that the Primary average self-efficacy score of students in PDL class is lower than the DL class. The standard deviation of The primary students' selfefficacy data in the PDL class is higher than the DL class. This shows that the distribution of The primary students' self-efficacy scores in the PDL class is more heterogeneous than the DL class. The final student self-efficacy data in the PDL class and DL class were obtained from the score of the self-efficacy scale carried out at the end of the meeting. The recapitulation of the final student self-efficacy scale scores is presented in Table 5.

Tabel 5. The Final Data of Self -Efficacy Student

\begin{tabular}{cccccc}
$\begin{array}{c}\text { Group } \\
\text { Research }\end{array}$ & $\begin{array}{c}\text { Amount of } \\
\text { Student }\end{array}$ & Average & $\begin{array}{c}\text { Standard } \\
\text { Divination }\end{array}$ & $\begin{array}{c}\text { The Lowest } \\
\text { Value }\end{array}$ & $\begin{array}{c}\text { The Highest } \\
\text { Value }\end{array}$ \\
\hline PDL & 35 & 111,486 & 3,128 & 104 & 119 \\
\hline DL & 35 & 98,371 & 3,326 & 89 & 104 \\
\hline & & Ideal Maximum Score $=100$ & & \\
\hline
\end{tabular}

\section{Description:}

PDL = Discovery Learning Development

DL = Discovery Learning

Min = Minimum Value 


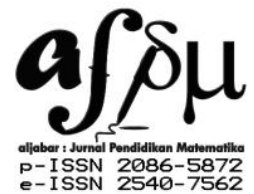

Al-Jabar: Jurnal Pendidikan Matematika

Vol. 9, No. 1, 2018, Hal $73-84$

Table 5 Shows that The Final average Score of Self-efficiency Student in the PDL class is Higher than The DL Class. The Standard Divination of the Self-efficiency student final score is Lower than DL Class. The Standard Divination of The standard deviation of the students' final self-efficacy in the PDL class is lower than the DL class. This shows the final self-efficacy score of DL class students is more heterogeneous than PDL class. The recapitulation of data on gain self-efficacy of students participating in PDL and DL is presented in Table 6.

Tabel 6. The Data of GainSelf-Efficacy Student

\begin{tabular}{|c|c|c|c|c|c|c|c|}
\hline No & Class & Value & $\mathrm{N}$ & Xmin & Xmaks & $\overline{\mathbf{x}}$ & N-gain Average \\
\hline \multirow[t]{2}{*}{1} & \multirow[t]{2}{*}{ PDL } & Pretest & \multirow[t]{2}{*}{35} & 68 & 96 & 80,48 & \multirow[t]{2}{*}{0,52} \\
\hline & & Posttest & & 104 & 119 & 111,48 & \\
\hline \multirow[t]{2}{*}{2} & \multirow[t]{2}{*}{ DL } & Pretest & \multirow[t]{2}{*}{35} & 66 & 97 & 81,62 & \multirow[t]{2}{*}{0,28} \\
\hline & & Posttest & & 89 & 104 & 98,37 & \\
\hline
\end{tabular}

\section{Keterangan:}

PDL = Discovery Learning Development

DL = Discovery Learning

Min = Minimum Value

Max = Maximum Value

$\overline{\mathrm{x}} \quad=$ Average

$\mathrm{s} \quad=$ Standard Divination

Based on Table 6 shows that the average gain self-efficacy index of students who use the development of discovery learning is higher than the average gain self-efficacy index of students who use discovery learning. Based on Table 6 the average gain index for the experimental class is 0.52 . This means that the increase in students 'self-efficacy ability using the development of discovery learning is included in the the medium criteria, while the increase in students' self-efficacy using discovery learning is included the low criterion with a mean gain class control index of 0.28 .

This means that the design of discovery learning models is effective to develop the student reflective thinking skills and self-efficacy. The research and development that encourages to improve the quality of teaching and learning in the classroom. The implementation of the discovery learning model must be balanced with the teacher's ability. The existence of training for the teacher about discovery learning can improve the teacher ability to carry out classroom learning (Rahayu, 2016). The teacher ability strongly influences the quality of learning outcomes, therefore the teacher must be more ready in preparing the learning model strategy. Basically The students' thinking ability, especially the ability to think reflective has a relationship with the ability of self-efficacy so that students who have good reflective thinking ability will have high self-efficacy be able to solve mathematical problems in order to obtain 
the appropriate results so that the student can be achieved the best quality of learning (Astutiningrum, 2016; Masri, 2018; Putra et.al., 2018).

\section{CONCLUSION AND SUGGESTION}

As the results of the research and development that were carried out, it can be concluded that the design of discovery learning models is effective for developing students' reflective thinking skills and self-efficacy. Based on the conclusions above there are some suggestions including: for further research can look for other learning models that are more influential on the ability of reflective thinking and self-efficacy of students and try to use the similiar model or other learning models by looking for the other influences or adding a review research on students' knowledge, affective, and psychomotor abilities. Hopefully this research can be useful and be a source of reference to further research.

\section{REFERENCES}

Al Majid, I. (2015). Penerapan Pembelajaran Reflektif Dalam Upaya Meningkatkan Kemampuan Berpikir Kritis Pada Pembelajaran Sepak Bola Siswa Kelas XI IPA 1 SMA Negeri 1 Ungaran Kabupaten Semarang Tahun 2013/2014. Journal of Physical Education, Sport, Health and Recreations , 4 (1), 1560-1566.

Angkotasan, N. (2013). Model PBL dan Cooperative Learning Tipe TAI Ditinjau dari Aspek Kemampuan Berpikir Reflektif dan Pemecahan Masalah Matematis. PYTHAGORAS: Jurnal Pendidikan Matematika , 8 (1), 92-100.

Astutiningrum, D. E. (2016). Improving Parenting Self Efficacy after Caesarean Section through Counselling. Jurnal Ners , 11 (1), 134-141.

Baskara Putra, K. W. (2017). Pengembangan E-Modul Berbasis Model Pembelajaran Discovery Learning Pada Mata Pelajaran "Sistem Komputer" Untuk Siswa Kelas X Multimedia SMK Negeri 3 Singaraja. Jurnal Pendidikan Teknologi dan Kejuruan , 14 (1), 40-49.

Ellianawati et al. (2014). Student's Achievement In Reflective Thinking Level Of Cognitive Apprenticeship Based Instruction Of Mathematical Physics 1 Remedial Program. Jurnal Pendidikan Fisika Indonesia , 10 (2), 150-157.

Fadriati. (2017). A Model of Discovery Learning Based - Text Book of Character and Islamic Education : An Accuracy Analysis of Student Book in Elementary School. Jurnal Ta'dib , 20 (2).

Haryanti, F. d. (2016). Pengembangan Modul Matematika Berbasis Discovery Learning Berbantuan Flipbook Maker Untuk Meningkatkan Kemampuan Pemahaman Konsep Pada Materi Segitiga. Jurnal Pendidikan Matematika , 1 (2), 147-161.

Haryati, T. H. (2017). Analisis Kemampuan dan Disposisi Berpikir Reflektif Matematis Siswa Ditinjau Dari Gaya Belajar. JPPM , 10 (2), 146-158. 
Isfayani, E. R. (2018). Peningkatan Kemampuan Koneksi Matematis dan Self- Efficacy Siswa Melalui Model Pembelajaran Kooperatif Tipe Rotating Trio Exchange (RTE). Jurnal Elemen , 4 (1), 80-92.

Istikomah, H. d. (2013). Pengembangan Perangkat Pembelajaran Metode Discovery Learning Untuk Pemahaman SAINS Pada Anak TK B. Journal of Primary Educational , 2 (2).

Jalil, M. S. (2016). Pengembangan Pembelajaran Model Discovery Learning Berbantuan Tips Powerpoint Interaktif Pada Materi Interaksi Makhluk Hidup Dengan Lingkungan. Jurnal Refleksi Edukatika , 6 (2), 130-137.

Late, M. N. (2017). Peningkatan Pemahaman Konsep Tekanan Hidrostatis dan Hukum Archimides Siswa SMP Melalui Pembelajaran Discovery. Jurnal Pendidikan: Teori, Penelitian, dan Pengembangan, 2 (9), 1215-1219.

Masri, M. F. (2018). Pengaruh Metode Pembelajaran Berbasis Masalah Terhadap Self-Efficacy dan Kemampuan Pemecahan Masalah Matematis Ditinjau Dari Kemapuan Awal Matematika Siswa SMA. JPPM, 11 (1), 116-126.

Mentari, N. H. (2018). Analisis Kemampuan Berpikir Reflektif Siswa SMP Berdasarkan Gaya Belajar. Jurnal Matematika dan Pendidikan Matematika , 2 (1), 69-98.

Nindiasari, H. N. (2016). Pengembangan Bahan Ajar Untuk Meningkatkan Tahapan Kemampuan Berpikir Reflektif Matematis. JPPM , 9 (1), 109-115.

Noer, Sri Hastuti. 2010. Peningkatan Kemampuan Berpikir Kritis, Kreatif, dan Reflektif (K2r) Matematis Siswa SMP Melalui Pembelajaran Berbasis Masalah. S3 thesis, Universitas Pendidikan Indonesia.

Putra et.al. (2018). Kemampuan Mengidentifikasi Kecukupan Data Pada Masalah SPLDV dan Self-Efficacy Siswa MTs. JNPM : Jurnal Nasional Pendidikan Matematika , 2 (1), 4861.

Rahayu, S. B. (2016). Pengembangan Model Diklat Guru Sosiologi SMA Tentang Strategi Pembelajaran Discovery Inquiry Berbantuan CD Interaktif. Jurnal Manajemen Pendidikan , 3 (1), 131-147.

Rasyid, M. A. (2017). Profil Berpikir Reflektif Siswa SMP dalam Pemecahan Masalah Pecahan Ditinjau dari Perbedaan Gender. KREANO: Jurnal Matematika Kreatif Inovatif , 8 (2), 171-181.

Rosdiana, D. T. (2017). Pengaruh Penggunaan Model Discovery Learning TerhadapP Efektivitas dan Hasil Belajar Siswa. Jurnal Pendidikan: Teori, Penelitian, dan Pengembangan , 2 (8), 1060-1064.

Sani, B. (2016). Perbandingan Kemampuan Siswa Berpikir Reflektif dengan Siswa Berpikir Intuitif di Sekolah Menengah Atas. Jurnal Pendidikan Matematika dan Sains , 4 (2), 63-76. 
Setiani, I. B. (2017). Bimbingan Kelompok dengan Pengajaran Formula ABCDE Pendekatan Rasional Emotif Behavior untuk Meningkatkan Self Efficacy Mahasiswa Calon Guru. Jurnal Kajian Bimbingan dan Konseling , 2 (1), 9-17.

Somawati. (2018). Peran Efikasi Diri (Self Efficacy) terhadap Kemampuan Pemecahan Masalah Matematika. Jurnal Konseling dan Pendidikan , 6 (1), 39-45.

Sukmasari, V. P. (2017). Pengembangan Penilaian Proyek Pembelajaran IPA Berbasis Discovery Learning untuk Mengukur Keterampilan Pemecahan Masalah. Jurnal Inovasi Pendidikan IPA , 3 (1), 101-110.

Wardani, U. A. (2014). Pengembangan Model Pembelajaran Discovery Learning dengan Data Sharing Technology pada Pokok Bahasan Energi. (23-25, Penyunt.) JRKPF , 1 (1).

Yusuf, M. d. (2015). Penerapan Model Pembelajaran Discovery Learning Menggunakan Pembelajaran Tipe Shared dan Webbed untuk Meningkatkan Keterampilan Proses Sains. Jurnal Penelitian \& Pengembangan Pendidikan Fisika , 1 (2), 19-26.

Yusuf, M. d. (2015). Peningkatan Prestasi Belajar dan Keaktifan Siswa Kelas XI MIPA-3 SMA Negeri 3 Cilacap melalui Model Discovery Learning Berbantuan Media Inovatif dan Software Pesona Fisika Materi Teori Kinetik Gas Tahun 2015/2016. Jurnal Penelitian \& Pengembangan Pendidikan Fisika , 1 (2), 19-26. 